Sarina Bakićl

UDK: $316.74: 374.7$

\title{
KLJUČNI ASPEKTI SOCIOLOGIJE OBRAZOVANJA
}

\section{- Sažetak -}

Kao samostalna empirijska i teorijska nauka, sociologija obrazovanja proučava uzajamne odnose između društva i obrazovanja, društvenoistorijsku i kulturnu uslovljenost procesa obrazovanja, te njegovu unutrašnju strukturu. Sociologija obrazovanja predstavlja riznicu ključnih promišljanja o promjenama u obrazovanju i njihovom uticaju na društvene promjene $u$ cjelini. U ovom tekstu akcentiraju se neki od ključnih socioloških aspekata obrazovanja, kao što su jednakost mogućnosti za obrazovanje, obrazovanje odraslih i slobodno vrijeme. Tekst promišlja budućnost obrazovanja iz sociološke perspektive.

Ključne riječi: društvo, jednakost, obrazovanje, odrasli, promjene, slobodno vrijeme, sociologija.

„,Na kraju, dok um kreira obrazovanje, obrazovanje kreira um." Jerome Bruner, Kultura obrazovanja

1 Mr. sc. Sarina Bakić, Fakultet političkih nauka, Univerzitet u Sarajevu. E-mail: sarinabakic@hotmail.com. 


\section{Uvod}

Kriza obrazovanja, o čemu se u posljednje vrijeme toliko govori, jeste samo izraz jedne daleko veće krize, krize duhovne situacije vremena (Jaspers, 1987) u kojem živimo. Također, teškoće u određivanju uloge obrazovanja u društvu, zbog čega se pribjegava koliko smislenim toliko i besmislenim reformama, predstavljaju posljedicu preispitivanja cjelokupnog sistema vrijednosti savremene naučno-tehničke civilizacije, koja je u posve novoj fazi u kojoj dominiraju digitalne tehnologije, čiji se domašaji i perspektive ne mogu posve razumjeti, niti predvidjeti. Naravno, problem u ovom kontekstu ne predstavljaju nove tehnologije same po sebi, već se on nalazi u njihovim primjenama, njihovom razumijevanju i kreiranju odnosa prema svijetu i čovjeku uopšte.

Uloga obrazovanja (i vaspitanja) u razvoju bilo kojeg društva pokazuje stepen razvoja koji je društvo dostiglo. Društvo govori o sebi odnosom prema obrazovanju, odnosom prema stvarnim vrijednostima koje ono pokreće, jer osim što predstavlja egzistencijalnu činjenicu ljudskog postojanja, umreženo je u sve aspekte čovjekovog života.

Relacija između globalnog društva i obrazovanja, kao i procesi unutar sfere obrazovanja, predstavljaju osnovne probleme sociologije obrazovanja. Glavno pitanje koje proizlazi iz istraživanja ovih odnosa jeste na koji način savremeni procesi i promjene u obrazovanju (i vaspitanju) utiču na položaj i perspektive ličnosti odnosno pojedinca. Navedeni odnosi se uglavnom istražuju i promišljaju unutar dviju međusobno suprotstavljenih teorija (Koković 1992: 5). Prva: teorijska orijentacija prema kojoj obrazovanje predstavlja isključivo sredstvo reprodukcije postojećih društvenih struktura i druga: teorija koja akcentira sposobnost obrazovanja za oblikovanje novog tipa društva, prema kojoj obrazovanje predstavlja značajan faktor u reformaciji savremenih društava.

Prva teorija svoje polazište nalazi u društvenim uslovima u kojima nastaje određeni obrazovni sistem te se on ne može sagledavati bez praćenja i analiza promjena u društvu i uslova u kojima se dato društvo nalazi. Navedeno ukazuje da u ovom slučaju društvo implicira ciljeve obrazovanja i okolnosti u kojima se obrazovanje (i vaspitanje) realizuje, uslovljava promjene i vrstu promjena u obrazovanju kojima održava postojeći društveni sistem. Za razliku od ovog teorijskog pristupa, $\mathrm{u}$ drugom postoji određena nezavisnost obrazovanja od društvenih, pa tako i ekonomskih faktora. Baš kako može stagnirati u odnosu na društvo i njegove potrebe, tako obrazovanje može biti značajan faktor u promovisanju tehničkih moći i dominacije, što za posljedicu može imati 
ignorisanje značaja i vrijednosti humanističkog obrazovanja.

Iz ovog kratkog obrazloženja, jasno je da promišljanje odnosa unutar obrazovanja i prema obrazovanju ne mogu zadovoljiti pojedinačno oba ova teorijska pristupa. Naime, svaka promjena u obrazovanju i svaka promjena $\mathrm{u}$ društvu imaju svoja nezavisna postojanja bez obzira na njihovo planiranje, usmjeravanje, načine na koje se ocjenjuju ili prate. Tako se mnogi procesi i rezultati ostvaruju djelimično ili su u pitanju brojne neusklađenosti, ponekad i nelogičnosti, kada je u pitanju postignuto. Naprimjer, uključivanje što većeg broja mladih ljudi u obrazovanje je trebalo prvenstveno ojačati demokratizacijske procese i ublažavati i smanjivati društvene nejednakosti (Pašalić-Kreso, 1986). Međutim, ekspanzija obrazovanja u kvantitativnom pogledu rezultirala je očuvanjem i reprodukcijom društvenih nejednakosti. Neadekvatno i usporeno napredovanje u pogledu obrazovanja (i vaspitanja) kao i kvaliteta života jasno usmjeravaju na teorijska promišljanja koja se uglavnom povezuju sa funkcijom prilagođavanja obrazovanja, ali i ličnosti uopšte, zahtjevima aktuelnog društvenog sistema. Tako je u ovom kontekstu potrebno izdvojiti konkretne sociološke probleme, s aspekta navedenih teorijskih promišljanja, sa naglaskom na kontinuiranoj problematizaciji jednakosti mogućnosti za obrazovanje, rekonceptualizaciji obrazovanja odraslih u sociološkom kontekstu te slobodnom vremenu kao društvenom fenomenu koji iziskuje znatno ozbiljniji pristup u proučavanju. Ovim se nameće i produbljivanje problematike budućnosti obrazovanja $\mathrm{s}$ aspekta sociološke nauke.

\section{Problemi istraživanja u sociologiji obrazovanja}

Razvoj društvenih nauka i njihovo diferenciranje na samostalne naučne discipline korespondira s porastom značaja obrazovanja u savremenom svijetu. Kada se govori o istraživanju i tumačenju sociološkog aspekta obrazovanja, većina sociologa se slaže da je u pitanju posebna sociološka disciplina sociologija obrazovanja, koja teorijski i empirijski istražuje uzajamne odnose društva i obrazovanja, društvenu, istorijsku i kulturnu uslovljenost procesa obrazovanja, te njegovu unutrašnju strukturu. Sociologija obrazovanja, kao i ostale sociološke discipline, ,predstavlja pograničnu nauku na temeljima opšte sociološke teorije i izučava svekupnost uzajamnih veza društvoobrazovanje" (Koković 1992: 9-10). Kada je u pitanju specifikacija predmeta ove sociološke discipline, izdvajaju se dva osnovna polja: polje uzajamnog odnosa između ukupnog društva i obrazovanja i polje društvenih procesa i odnosa unutar sfere obrazovanja. 
$\mathrm{Na}$ osnovu ove specifikacije nastaje mreža zasebnih problematika u kontekstu odnosa sistema institucionalnog obrazovanja sa ostalim dijelovima društva, zatim strukture i funkcionisanja škola i univerziteta sa različitih društvenih aspekata (demografskog, ekonomskog, kulturnog, političkog itd.), društvenih procesa unutar obrazovnih institucija i društvenih uslova koji utiču na funkcionisanje obrazovnog sistema. Kako bi se u istraživanju ovih pitanja izbjegli nedostaci empirije i parcijalnog zaključivanja, neophodna je veza između sociologije obrazovanja i opšte sociologije, kao i sa drugim društvenim naukama koje se bave izučavanjem obrazovanja iz različitih aspekata $^{2}$.

Važno je naglasiti da problem sociologije obrazovanja također uključuje i sve one aspekte koji su izvan institucionalnih okvira, a koje ova naučna disciplina obuhvata kada je u pitanju pojam ,socijalizacija ličnosti”. Pod ovim pojmom se podrazumijeva proces razvoja ličnosti, ali su njime obuhvaćeni i svi faktori koje pomenuti proces podrazumijeva. Prije svega, riječ je o faktoru koji se označava kao vaspitanje, zatim o komunikaciji u porodici i unutar dječijih druženja, uticajima koji se ostvaruju preko lokalne sredine, predškolskih ustanova i vjerskih institucija i zajednica, ali i specifičnim uticajima koji se realizuju putem masovnih medija i poruka koje oni emituju, a ugrađeni su u svakodnevni kontekst društvenih odnosa.

Velik značaj u razmatranju teorije i prakse obrazovanja ima filozofski pristup u obrazovanju, koji odnos između obrazovanja i filozofije promišlja u kontekstu istorijskog razvoja. Zapravo, riječ je o sagledavanju tog odnosa i procesa promjena sa aspekta ideje obrazovanja. Filozofija obrazovanja ima za krajnji cilj tematizovanje prirode znanja i sve vidnijeg odsustva potrebe za znanjem u savremenom svijetu. Riječ je o jednoj svojevrsnoj fenomenologiji obrazovanja i pedagogije u svijetu lišenom vrijednosti za kojima skoro većina ne osjeća potrebu. Razumije se, takva fenomenologija ostaje moguća čak i u situaciji odsustva potrebe za mišljenjem, u jednom samozadovoljnom potrošačkom svijetu kojem 'mišljenje mišljenja' ostaje nepristupačno, i prebiva s one strane svake filozofske teorije i prakse. Činjenica jeste da su ranije epohe imale sklonost da se, kada je riječ o problemima obrazovanja (i vaspitanja), manje pažnje pridaje njihovoj teoriji i njihovom diskurzivnom

2 Opšta sociologija svoje polazište nalazi u globalnom društvenom sistemu, istražuje, analizira i interpretira povezanost specifičnih društvenih pojava i procesa sa društvom u cjelini. Kako bi sociološko proučavanje položaja i uloge pojedinca u društvu bilo svrsishodno, sociološka teorija treba da bude antropološki i kulturološki zasnovana, a da bi se određeni fenomen izučavao sociološki, potrebno je da se taj isti fenomen posmatra u zavisnosti od cijelog niza fenomena kojima je uslovljen i koji mu prethode. 
osmišljavanju, a daleko više samoj obrazovnoj praksi, čiji su se rezultati uglavnom odnosili na mjeru uspjeha u širenju znanja.

Objašnjenje uglavnom treba tražiti u činjenici da teorije uvijek ostaju nedovršene, sklone osporavanju, proširivanju i raspravama, dok praksa postavlja sasvim konkretne i u većini slučajeva neodložne zahtjeve, nezavisno od toga da li će teorija voditi pozitivnim ili negativnim rezultatima. Iz ovoga proizlazi kod mnogih već ustaljeno mišljenje kako se vrlinama možemo učiti u praktičnom djelovanju, nezavisno od teorijskih promišljanja, kao i da visoka teorijska promišljanja ne moraju biti garancija napredovanja kada je u pitanju razvoj osnovnih ljudskih vrlina ${ }^{3}$.

Postavlja se konačno pitanje koji su to razlozi bili važni za pojavu sociologije obrazovanja. Uzimajući u obzir i uvažavajući činjenicu da su oni raznovrsni i brojni, te da ih je teško sve obuhvatiti, Sergej Flere apostrofira najvažnije:

- slaba djelotvornost obrazovanja;

- veliki troškovi obrazovanja i njihov stalni rapidni porast;

- teško uključivanje đaka i studenata u područje rada;

- povećanje devijantnog i agresivnog ponašanja mladih;

- teškoće u koordinaciji među institucijama obrazovnog sustava;

- $\quad$ sve snažniji sukob generacija, te

- $\quad$ spoznaja da navedene i slične probleme ne može razriješiti samo pedagogija (Flere 1976: 11).

Ovi navedeni istraživački problemi, koji su ujedno i istraživački problemi pedagogije i andragogije predstavljaju relevantnu istraživačku problematiku sociologije obrazovanja.

\section{Jednakost mogućnosti za obrazovanje}

Za sociologiju obrazovanja su značajne posljedice društvenih nejednakosti u obrazovanju. Od velike je važnosti razlikovati uzroke od posljedica nejednakosti na osnovu toga da li djeluju na obrazovanje u primarnoj ili

3 Ovakvo stanovište možemo naći kod većine pedagoga koji svu svoju djelatnost nastoje da fokusiraju na samu pedagošku praksu, te svoj glavni zadatak vide u razvoju tehnike vaspitanja i sticanja osnovnih znanja. Međutim, u ovom kontekstu, ako se postavi pitanje progresa same kulture kao zasebnog fenomena, većina će odgovoriti da progres zavisi od smjera i kojim putem se sprovodi vaspitanje i obrazovanje novih generacija, ali će se malo ljudi zapitati o kojem i kakvu je progresu ovdje zapravo riječ, da li ga u principu uopšte ima, te ako je odgovor potvrdan, onda je važno pitanje u kojim oblastima se to može konstatovati, pogotovo ako se prisjetimo Blochovog uvida o nužnom postojanju gubitka u svakom napredovanju (Bloch 1973: 137). 
sekundarnoj ravni. Primarni uticaj stratifikacije uključuje nejednakost u mogućnostima obrazovanja, konkretnije: potkulturne razlike između društvenih klasa koje proizvode stratifikacijski sistem, koje utiču na to da pripadnici pojedinih grupa postižu veći uspjeh i viši stepen u školovanju. Sekundarni uticaj je mnogo važniji, jer proizlazi iz stvarnog položaja određene osobe u klasnom ustrojstvu društva.

Najopštije rečeno, posljedice se najviše odnose na „nejednake aspiracije kada je u pitanju obrazovanje, nejednake troškove obrazovanja i na nejednaku efikasnost obrazovnog sistema" (Koković 2009: 70). Odnos društvene klase i obrazovnog postignuća jeste takav da društvene nejednakosti reprodukuju obrazovanje, a obrazovanje, s druge strane, postaje mjesto reprodukovanja društvenih nejednakosti, vrijednosti i očekivanja ${ }^{4}$.

Pitanje jednakosti mogućnosti za obrazovanje jeste veoma aktuelno u vremenu u kojem dominira meritokratski princip u objašnjavanju organizacije društva i socijalne stratifikacije, odnosno kada se osnovnim kriterijem i jednog i drugog počinju uzimati kompetencija i znanje a ne naslijeđeno pravo. Zastupnici meritokratske logike zaključivanja polaze od teze da izvor društvene stratifikacije u savremenim društvima ne mogu biti nikakva istorijska prava ili prava po osnovi nasljedstva vlasništva ili statusa, već samo razlike u znanju i kompetenciji ${ }^{5}$.

Obrazovne mogućnosti podrazumijevaju da svaki pojedinac, nezavisno od svojih potencijalnih sposobnosti, treba da dobije jednak udio obrazovnih resursa. Druga interpretacija jednakih mogućnosti odnosi se na to da svu djecu treba jednako tretirati bez obzira na to iz kog i kakvog okruženja dolaze. Također, jedna od interpretacija jeste i tzv. kompenzatorsko obrazovanje, čiji je smisao u popravljanju nepovoljnog položaja siromašne djece u odnosu na djecu sa povoljnijim društvenim položajem.

Socijalne nejednakosti i dostupnost obrazovanja poprimaju sve više ekonomski karakter. Razlike kada je u pitanju ekonomski položaj porodica ujedno predstavljaju i razlike među porodicama prema njihovim mogućnostima da školuju svoju djecu. Sa tim mogućnostima usko su povezane i aspiracije djece kada je njihovo obrazovanje u pitanju ${ }^{6}$. Također, uskraćivanja i lišavanja

4 Obrazovanje po definiciji ne vrši stratifikaciju u društvu, ono ga samo diferencira. Ljudi sa velikim znanjem najčešće ne predstavljaju društveni sloj bogataša, društvene aristokratije ili visokih funkcionera. Tamo gdje obrazovanje vrši stratifikaciju jeste veza obrazovanja sa ekonomijom, ekonomskim životnim mogućnostima, s društvenim ugledom, autoritetima, uticajem, moći itd.

5 U ovom kontekstu, obrazovanje može biti faktor značajnije društvene pokretljivosti.

6 Mnoga istraživanja su pokazala da postoji visoka povezanost između obrazovanja roditelja i profesionalnih težnji i dostignuća njihove djece. 
okoline mogu spriječiti dijete da realizuje svoje potencijale i talenat. Lako se može zaključiti da društveno okruženje i uslovi sredine imaju presudan značaj.

Jasno je da obrazovanje predstavlja jedan od relevantnih faktora kada je u pitanju stvaranje društvenih struktura savremenih društava. Savremena društva su otvorena društva koja karakteriše značajna vertikalna socijalna pokretljivost, koja je usko povezana s kategorijom obrazovanja. Naime, u društvima ovog tipa, društveni statusi se ne nasljeđuju, već se stiču iskazanim sposobnostima, talentom, interesom, sklonostima, ali i sopstvenim zalaganjem. Od navedenih karakteristika važno je da li će se pojedinac na skali društvene stratifikacije kretati prema naviše ili će to kretanje imati silaznu putanju. Shodno ovome, navedene karakteristike su direktno vezane i za proces obrazovanja. Prema tome, mogućnosti za društvenu promociju jesu u direktnoj vezi s mogućnostima za obrazovnu promociju. Zato se može reći da je pitanje jednakosti obrazovnih mogućnosti i njihova stvarna primjena jedno od glavnih socioloških pitanja savremenih demokratskih društava.

\section{Rekonceptualizacija obrazovanja odraslih}

Bosna iHercegovina ima stogodišnju tradiciju institucionalnog obrazovanja odraslih. Poslije Drugog svjetskog rata ustanovljen je koncept koji je sredinom pedesetih godina dobio karakteristike sistema i bio inkorporiran na lokalnom i državnom nivou. Velik broj uspostavljenih univerziteta, znatan broj radničkih fakulteta, osnovnih škola za odrasle, večernjih srednjih i viših škola, s velikim brojem polaznika, uz sistemsku profesionalizaciju andragoških radnika, učinili su da je sistem obrazovanja u Bosni i Hercegovini bio jedan od najrazvijenijih, ne samo na prostorima tadašnje Jugoslavije nego i šire. Zato se s pravom govorilo da je u šezdesetim godinama prošlog vijeka sistem obrazovanja odraslih u Bosni i Hercegovini prolazio svoje ,zlatno doba". Nadalje, osamdesetih, a naročito devedesetih godina prošlog vijeka, koncept obrazovanja odraslih prolazi kroz svoju drastičnu inovaciju, kojom se naglašava potreba za cjeloživotnim učenjem i novim vrijednostima, koje neminovno proizlaze iz raznolikih promjena uslova života na globalnom nivou. Ideja cjeloživotnog obrazovanja predstavlja 'usistematizaciju' obrazovanja u svim životnim dobima (od djetinstva do starosti) i obuhvata sve oblike formalnog, neformalnog i informalnog obrazovanja (Pastuović 1999: 3). Kada se govori o obrazovanju odraslih, potrebno je uzeti u obzir težnju da se kreira kako racionalnije društvo tako i modernija država, što postaje jedna od nezaobilaznih i dominantnih ideja u sociologiji obrazovanja. 
Važno je naglasiti da, u ovom kontekstu, centralno pitanje obrazovanja postaje i informatičko obrazovanje.

Koncept obrazovanja odraslih je u suštini plod teorijskog istraživanja problema krize u obrazovanju. Nastavak operacionalizacije ovog koncepta iziskuje primjenu saznanja pojedinih obrazovnih i pedagoških nauka. Parafrazirajući Pastuovića, vidimo da tradicionalna pedagogija svojim normativnim i deskriptivnim karakterom (Pastuović 1999: 3) nije svoju pažnju usmjeravala na sve segmente obrazovanja odraslih kao što se to uočava kada su u pitanju osnovnoškolsko obrazovanje i opšte obrazovanje djece i mladih. Također, prema Paustoviću (1999: 3-4), pedagogija kao više praktična disciplina, više normativna nego eksplanativna, nije svoj interes usmjeravala na aspekte obrazovne i vaspitne stvarnosti niti na uslove i zakonitosti koje u toj stvarnosti djeluju, te se više bavila ciljevima vaspitanja prema kojima vaspitanje i obrazovanje treba biti usmjereno i sprovođeno. Naravno da se u ovom slučaju nikako ne zaobilazi andragogija, koja, iako fokusirana na obrazovanje odraslih, još uvijek ovo područje obrazovanja nije dovoljno teorijski obradila, naročito sa sociološko-kategorijalnih i fenomenoloških aspekata ${ }^{7}$. Obrazovanje odraslih se akcentira isključivo u sferi profesionalnog obrazovanja, odnosno njegovog povezivanja sa tržištem rada. Drugim riječima, kulturni ideal novog kapitalizma, odnosno vrijednosti nove ekonomije, postale su referentno mjesto o tome kakve se vještine i sposobnosti stiču kroz obrazovni sistem.

Iz ovoga proizlazi potreba rekonceptualizacije obrazovanja odraslih u kontekstu sociologije obrazovanja koja bi obuhvatila sva postojeća teorijska znanja iz ove oblasti. Novi interpretativni uvid u segmentu obrazovanja odraslih prvenstveno leži u antinomijama obrazovnih ciljeva. Prema Bruneru, u pitanju je funkcija obrazovanja da reprodukuje kulturu odnosno društvo koje ga podržava (Bruner 2000: 77) ali i da se zalaže za postojeće političke, kulturne i ekonomske ciljeve ${ }^{8}$. Ali, može li se obrazovanje odraslih osmisliti u isto vrijeme i kao instrument ličnog ostvarenja i preferencijalnog osposobljavanja? Odgovor na ovo pitanje sadrži veću dozu skepticizma zbog činjenice da se nesputani ideal individualnog ostvarenja itekako izlaže potencijalnoj opasnosti „društvene i kulturne nepredvidljivosti”, odnosno, ono je u mogućnosti da postane remetilački faktor legitimnog društvenog

7 Ovdje prvenstveno mislim na funkcionalističku analizu obrazovanja odraslih.

8 Bruner daje za primjer obrazovni sistem industrijskog društva (Bruner 2000: 78) u kojem treba proizvesti poslušnu radnu snagu, nekvalificirane i polukvalificirane radnike, službenike, menadžere srednjeg ranga itd., a koji su svi zajedno uvjereni da takvo društvo predstavlja jedini ispravan i valjan oblik života. 
poretka. Obrazovanje (odraslih), dirkemovski kazano, kao kulturna reprodukcija donosi, a i svjedoci smo toga danas, hegemoniju, stagnaciju i konformizam. Naći neku vrstu 'srednjeg' rješenja je veoma teško, pogotovo ako uzmemo u obzir današnji tempo i vrste promjena na nivou cjelokupnog društva. Nadalje, u „društvu vještina” (Sennett 2007: 73) mnogi nezaposleni su obrazovane i osposobljene osobe, no posao koji bi oni željeli raditi jeste sada u mjestima gdje je rad jeftiniji te su im zbog toga potrebne drugačije vještine. Ukoliko razmislimo koliko dugo traje neko stručno znanje odnosno vještina, uspostavlja se još direktnija veza između godina i pitanja talenta. Naprimjer, ako je neko mašinski inžinjer, koliko dugo će se ta osoba moći služiti znanjem koje je stekla na fakultetu? S vremenom, sve manje. Prema Sennettu, ,odumiranje vještina” ne ubrzava se samo u tehničkim profesijama već se ova pojava odnosi i na pravnike, medicinare, i zaposlene u drugim oblastima rada. U tom smislu, postoje procjene kako „serviseri računara treba da obnove svoje stručno znanje tri puta tokom radnog veka; procena je otprilike ista i za lekare" (Sennett 2007: 82).

Nadalje, osobe koje započnu ali ne završne redovno obrazovanje posebna su društvena problematika. Razlozi ovakvog osipanja mogu se pretpostaviti u nedovoljnoj vertikalnoj i horizontalnoj prohodnosti redovnog obrazovnog sistema te nerazvijenom modelu individualizacije učenja. Od velike je važnosti izgradnja sistemskog pristupa svakom „obeshrabrenom” pojedincu i modela uspješne dodatne motivacije za integraciju ${ }^{9}$ u proces učenja odnosno proces rada te uzimanje aktivne uloge u društvu.

Kada se govori o cjeloživotnom učenju, praksa obrazovanja odraslih bilježi sve veće zanimanje za visoko obrazovanje odraslih osoba, koje je motivirano napredovanjem u struci, željom ili potrebom za promjenom profesije, te ličnim potrebama i željama pojedinca. Odgovor na ove potrebe obrazovanje može ponuditi otvorenijim i fleksibilnijim pristupom, što bi, svakako, unaprijedilo obrazovnu strukturu stanovništva u ovome, za razvoj društva, posebno važnom segmentu obrazovnog sistema.

Sadašnjim reformama obrazovanja, naročito administrativnim „nasiljem”, oštećen je koncept obrazovanja odraslih, a do tada su dobro organizovane institucije - nosioci ovog obrazovanja - potisnute na marginu dešavanja $u$ savremenom obrazovanju i kulturi. Ovdje prvenstveno mislim na razvijanje kulture učenja te na izgradnju shvatanja učenja kao dominantne društvene vrijednosti.

9 Prvenstveno se ovo odnosi na nezaposlene osobe, ratne invalide, civilne žrtve rata, osobe sa različitim oblicima invaliditeta i ostale marginalizovane društvene grupe. 


\section{Slobodno vrijeme - sociološki i obrazovni fenomen}

U kontekstu Adornove tvrdnje da u „društvu koje odvikava ljude da misle dublje o sebi, biva suvišno sve ono što premašuje reprodukovanje njihovog života i na šta su prisiljeni kao da ne bi mogli bez toga" (Adorno 1979: 397), čini se da u novonastaloj situaciji jedan od ključnih problema u kontekstu obrazovanja jeste još jedan sociološki fenomen, a to je slobodno vrijeme.

Prema promišljanjima Nenadića (1997), slobodno vrijeme u pojmovnom i istorijskom smislu predstavlja rezultat industrijskog društva, čiji je karakter u suprotnosti sa radnim vremenom, te prije svega i nakon svega, naročito kada su u pitanju djeca i mladi ljudi - pedagoški problem. Mladi ljudi jesu specifična društvena grupa te je zbog nedostatka životnog iskustva potreban, kako navodi Previsić (2000), ,intencijalni napor društva kako prostor slobodnog vremena ne bi postao prostor besmisla ili mogućih društveno nepoželjnih oblika ponašanja mladih", čije posljedice predstavljaju posljedice za društvo u cjelini.

Često ignorirajući ovu sociološku problematiku, mnogi nastoje i da ga „ispune” tako što će ga s predumišljajem ispuniti krajnje besmislenim, neproduktivnim i kičerskim medijskim sadržajima, beskrajnim televizijskim serijama, satima provedenim na sajtovima i blogovima „kulturnog polusvijeta”. Izdvaja se potreba nedopuštanja postojanja slobodnog vremena kao takvog, jer ono itekako može biti korišteno u „destruktivne svrhe” po sistem i ideologije čija je svrha neutralisati slobodu mišljenja i slobodno vrijeme, te prazno vrijeme ispuniti besmislom u formi prividnog smisla. Ljudima se već odavno pružila mogućnost da satima na internetskim forumima istroše svoju negativnu energiju i obesmisle onu pozitivnu i na taj način postanu duboko odvojeni od stvarnosti, koja ostaje „strogo kontrolisana”, što na krajnje imanentan način uslovljava i obrazovanje (i vaspitanje). Svemu ovome potpomogla je u znatnoj mjeri odveć realizovana marcuseovska atomizacija društva, svođenje društva na skup jednodimenzionalnih i nekomunikativnih pojedinaca. Pojedinac modernog društva, prepušten sam sebi, a u kontekstu provođenja velikog dijela slobodnog vremena na internetskim forumima, facebooku i sl., predstavlja idealan primjer iluzije da tako utrošeno slobodno vrijeme ima neki uticaj i rezonantnost. Sve svoje strasti, posebno komplekse, frustracije te neostvarene ambicije, pojedinci pokušavaju zadovoljiti na ovakav način, koji prima sve njihove „vapaje” i „mudrosti” da bi ih slagao u sve niže slojeve povećavajući se tako kao „deponija svega i svačega” (Uzelac 2013: 16). U svemu ovome i leži bit provođenja slobodnog vremena na socijalnim mrežama: dati ljudima iluziju samostalnosti i odlučivanja, pružiti 
im iluziju o sopstvenoj smislenosti i važnosti, te multiplikacijom tog osjećaja razvijati sve više njihovu otuđenost i intelektualnu skučenost. Do te mjere da nikog osim sebe više ne poštuju niti cijene. Mentalni život postaje skučen i površan. Socijalna referenca, čulno rezonovanje i emotivno razumijevanje u ovom slučaju su isključeni.

Ako pod slobodnim vremenom podrazumijevamo i prostor u kojem osobe ostvaruju i razvijaju svoju ličnost, ostvaruju svoju integraciju u društvo, samorealizaciju, ispunjavaju svoje potrebe i realiziraju interese, razumljiva je potreba da se ovaj fenomen što bolje razumije, unaprijedi i istražuje. Iako ova tvrdnja proizlazi iz ciljeva odgoja u cjelini i uloge obrazovnih institucija $u$ organizaciji slobodnog vremena, važno je akcentirati potrebu za sociološkim istraživanjima u ovoj oblasti i korištenjem već postojećih analiza. O kulturi slobodnog vremena se u Bosni i Hercegovini veoma malo govori, dok aktivnosti koje u ovom domenu sprovode osnovne i srednje škole, tzv. „vannastavne aktivnosti”, nisu u kapacitetima koji odgovaraju potrebama i interesima mladih ljudi. Zato je, između ostalog, veoma važno, sa sociološkog aspekta, istražiti percepciju idealnog načina provođenja slobodnog vremena mladih ljudi te (ne)usklađenosti željenog i stvarnog provođenja tog vremena.

Sociološke interpretacije i izučavanja ovog značajnog društvenog fenomena mogu itekako biti polazna osnova pedagoškog izučavanja i pedagoške angažovanosti kada je u pitanju slobodno vrijeme.

\section{Ima li obrazovanje budućnost?}

Jedna od glavnih specifičnosti modernih društava leži u procesima kontinuiranih promjena. Zato je promišljanje o budućnosti obrazovanja izuzetno teško i nezahvalno. Međutim, moguće je i opravdano pokušavati odgovoriti na pitanje kakvo bi obrazovanje trebalo biti i kakva bi uloga obrazovanja trebala biti u životu današnjeg čovjeka. Za obrazovni sistem danas se često kaže da je u ,razvojnoj krizi”. Prije svega, ova sintagma se odnosi na sistem školskog obrazovanja; posljednjih trideset godina odlikuje ga niz uzastopnih reformi čiji su postignuti rezultati znatno manji od očekivanih.

Američki sociolog Christopher Jenkcs (Flere 1986: 280) smatra da reforma nije, prije svega, odgovorila zahtjevu za stvaranjem jednakosti među ljudima. Također, on smatra da je to prilično nerealan zahtjev za svaku reformu i naglašava da su djeca, prema njegovom mišljenju, još uvijek pod većim uticajem onoga što se dešava kod kuće nego onoga u školi. Osim toga, kreatori reformi obrazovanja nemaju, ili imaju veoma neznatnu kontrolu nad onim dimenzijama školskog života koje imaju najveći uticaj na djecu. Konačno, 
ako se i postigne određen uticaj škole na djecu, promjene koje iz tog uticaja nastanu ne prenose se na svijet odraslih. Za razliku od Jenkcsa, Zsuzsa Ferge (Flere 1986: 295) smatra da reforma obrazovanja ne samo da nije ispunila očekivanja nego je rezultirala ogromnim razočarenjima, jer se činila efikasnim sredstvom za smanjivanje društvene nejednakosti i stvaranje boljeg društva. U pitanju je razočarenje društvenim reformama uopšte, odnosno uvjerenje da je svako ustrajavanje na reformama besmisleno.

Bez obzira na rezignirana promišljanja nekih od vodećih teoretičara sociologije obrazovanja, novu krizu obrazovanja, posebno $\mathrm{s}$ aspekta informatičkog društva, treba dočekati ili spriječiti novom reformom obrazovanja. Svaka nova generacija trebala bi iznova promišljati u čemu se sastoji smisao i značaj promjena u društvu i obrazovanju, kakvo obrazovanje jeste i u kom pravcu bi trebalo usmjeravati njegov razvoj, njegove reforme. Pristalica sam sociološke orijentacije koja u uslovima informatičkog društva naglašava da su najvažniji zadaci obrazovanja da razvija čovjeka, da povlači svoje ciljeve pukog prenošenja činjenica i „,̌istog” znanja, da se u škole uvodi savremena tehnologija u kontekstu sprečavanja pozicije obrazovnih institucija na marginama informatičkog društva da osnovni zadatak vaspitanja i socijalizacije bude psihički stabilan pojedinac, intelektualno budan i duhovno human, koji će znati koristiti informacije, da u njegovoj strukturi svijesti važnu ulogu ima ekološki kriterij odnosa čovjeka i prirode, te da nastavnik ne bude samo prenosnik znanja i činjenica, pojedinih informacija, već da bude i vaspitač koji će pomoći učenicima u stvaranju etičkih normi (Cifrić 1990: 195-196).

\section{Zaključna razmatranja}

Razmišljanja u ovom tekstu naglašavaju da sociološka razmatranja obrazovanja podrazumijevaju onu vrstu analiza koje suštinu, strukturu, funkciju i kvalitet obrazovanja analiziraju u odnosu na društveni kontekst, društvenu uslovljenost obrazovanja, ali i povratni uticaj obrazovanja na različite oblasti društvenog, kulturnog i političkog života.

Također se trebamo zapitati koji su to faktori, društvene i istorijske situacije u našem društvu, koji dovode do toga da se današnje obrazovanje i promišljanja o njemu pojavljuju za čovjeka kao svijet idealnih objektivizacija suprotstavljenih njegovom stvarnom životu i nezavisno od njega? Da li je to prirodno stanje, imanentno današnjoj masovnoj kulturi kao „apsolutu” ljudskog svijeta, ili je ono, ipak, rezultat društvenih odnosa i demokratizacije društva u cjelini? 
U svemu navedenom, kada su u pitanju reforme u obrazovanju, nameće se potreba za velikim zaokretom sa jasnijim osjećajem za to gdje smo se kao društvo zaputili, s dubljim uvjerenjem o tome kakvi ljudi trebamo biti. $\mathrm{U}$ atmosferi višegodišnjeg sistematskog urušavanja sistema obrazovanja $u$ cjelini u Bosni i Hercegovini, prvenstveno s aspekta uticaja politike i miješanje politike u ovaj najvažniji društveni segment, gledajući dugoročno, kriza u obrazovanju jeste i najopasniji dio sveopšte krize bosanskohercegovačkog društva, što nosi nesagledive posljedice.

Potrebno je pokrenuti sveobuhvatnu društvenu akciju, koja će se zaista moći pozabaviti budućnošću našeg obrazovnog sistema - akciju u kojoj će svi resursi znanja, uma i elementarnog ljudskog saosjećanja koji su nam dostupni biti na raspolaganju svim obrazovnim institucijama. Sve akreditacije i standardi ovog svijeta neće puno pomoći da naše urušeno i ugroženo bosanskohercegovačko društvo ponovo oživi. Ne da oživi samo kao konkurent na evropskim tržištima, nego da zaživi kao društvo u kojem je vrijedno živjeti i raditi.

\section{KEY ASPECTS OF THE SOCIOLOGY OF EDUCATION}

\section{- Abstract -}

As an independent empiric and theoretical science, the sociology of education is discovering mutual relations between education and society, socio-historical and cultural conditionality of educational process and its internal structure. Sociology of education signifies a treasury of key estimations concerning necessary alterations in education and about their influence towards social changes as a whole. This text underlines some of the key sociological aspects of educations such are education equality, adult life long education and leisure. It revolves applicable ideas about the future of education from sociological perspective.

Key words: society, education, adults, equality, leisure, reforms, sociology. 


\section{Literatura}

- Adorno, Theodor W. (1979) Estetička teorija, Nolit, Beograd.

- Bloch, Ernst (1973), Tibingenski uvod u filozofiju, Nolit, Beograd.

- Božović, Ratko (1975) Iskušenja slobodnog vremena, Mala edicija ideja, SSOJ, Beograd.

- Bruner, Jerome (1996) The Culture of Education, Harvard University Press.

- Bruner, Jerome (2000) Kultura obrazovanja, Educa, Zagreb.

- Cifrić, Ivan (1990) Ogledi iz sociologije obrazovanja, Školske novine, Zagreb.

- Flere, Sergej (1976) Obrazovanje u društvu, Gradina, Niš.

- Flere, Sergej (1986) Proturječja suvremenog obrazovanja - ogledi iz sociologije obrazovanja, RZRK SSO, Zagreb.

- Jaspers, Karl (1987) Duhovna situacija vremena, Književna zajednica Novog Sada, Novi Sad.

- Koković, Dragan (1992) Sociologija obrazovanja, Matica srpska, Novi Sad.

- Koković, Dragan (2009) Društvo i obrazovni kapital, Mediteran Publishing, Novi Sad.

- Lesourne, Jacques (1993) Obrazovanje i društvo: izazovi 2000. godine, Educa, Zagreb.

- Nenadić, Mile (1997) Novi duh obrazovanja, Prosveta, Beograd.

- Pastuović, Nikola (1999) Edukologija - integrativna znanost o sustavu cjeloživotnog obrazovanja i odgoja, Znamen, Zagreb.

- Pašalić-Kreso, Adila (1986) Nejednakosti u vaspitanju i obrazovanju mladih, Veselin Masleša, Sarajevo.

- Pilić, Šime (2007) Sociologija nastavnika-od sociologije obrazovanja do sociologije profesije, u: Nacionalni sociološki kongres, Split, 30.31. 3. 2007., Knjiga sažetaka, Zagreb: Hrvatsko sociološko društvo, str. 25.

- Previšić, Vlatko (2000) Slobodno vrijeme između pedagogijske teorije i odgojne prakse, Napredak, 141 (4), str. 403 mn -410, Zagreb.

- Sennett, Richard (2007) Kultura novog kapitalizma, Arhipelag, Beograd. 
- Uzelac, Milan (2012) Filozofija obrazovanja I, Filozofske osnove savremenih pedagoških teorija, Visoka škola strukovnih studija, Vršac.

- Žiga, Jusuf (2013) Kako harmonizirati oficijelnu i cjeloživotnu (kontinuirano-inovativnu) obrazovnu djelatnost?, Obrazovanje odraslih, 2/2013, str. 11-19, Sarajevo. 